\begin{tabular}{|l|l|l||}
\hline \multicolumn{2}{|c|}{ PublisherInfo } \\
\hline \hline PublisherName & $:$ & BioMed Central \\
\hline \hline PublisherLocation & $:$ & London \\
\hline \hline PublisherImprintName & $:$ & BioMed Central \\
\hline \hline
\end{tabular}

\title{
UTI rates from catheter systems in the ICU
}

\begin{tabular}{|l|l|l||}
\hline \multicolumn{2}{|c||}{ ArticleInfo } \\
\hline \hline ArticleID & $:$ & 4312 \\
\hline \hline ArticleDOI & $:$ & $10.1186 /$ ccf-2001-73400 \\
\hline \hline ArticleCitationID & $:$ & 73400 \\
\hline \hline ArticleSequenceNumber & $:$ & 23 \\
\hline \hline ArticleCategory & $:$ & Paper Report \\
\hline \hline ArticleFirstPage & $:$ & 1 \\
\hline \hline ArticleLastPage & $:$ & 3 \\
\hline \hline & & RegistrationDate : 2001-12-5 \\
ArticleHistory & $:$ & Received \\
\hline \hline ArticleCopyright & $:$ 2001-8-23 \\
\hline \hline ArticleGrants & $:$ & OnlineDate \\
\hline \hline ArticleContext & $:$ & 1305455 \\
\hline \hline
\end{tabular}


Aff1 Christiana Healthcare Systems, Wilmington, DE, USA

\section{Keywords}

Cross infection, intensive care units, nosocomial infection, urinary catheterization, urinary tract infections

\section{Context}

Catheter associated urinary tract infections are a common cause of nosocomial infection in the ICU. It has been hypothesized that a urinary catheter without an antireflux valve may allow bacteria to ascend the urinary tract without having to overcome the normal physiological barriers. This study compares the incidence of urinary tract infections (UTIs) in patients with a two chamber, open drainage system (TCOS), which has no protection from reflux, to the incidence in patients with a complex closed drainage system (CCDS). The CCDS has an antireflux valve, drip chamber, and an iodine releasing cartridge, which are employed to decrease the reflux of urine and to eradicate bacteria.

\section{Significant findings}

A total of 224 patients were entered into the study. Gender, age, and physiology scores were similar but the TCOS group had a higher incidence of adult respiratory distress syndrome. Bacteriuria occurred in $12 \%$ of patients and started on average, 2 weeks after catheter insertion. Women were more likely to have bacteriuria than men $(22 \%$ versus $8 \%)$. Non-UTI infections were treated in $75 \%$ of the population. The surgical and trauma patients had a higher incidence of bacteriuria than the medical patients. Some of the organisms that caused bacteriuria differed between the groups, although there were few data on this. There was no significant difference between open and closed drainage systems in prevention of nosocomial UTIs.

\section{Comments}

This study confirms that more expensive urinary collecting systems with antireflux valves are unlikely to reduce the incidence of catheter associated UTIs and hospital resources should not be wasted 
on them. It seems that there are other more important factors contributing to bacteriuria than reflux; previous articles have alluded to extraluminal contamination from the perineum. Some new catheters are impregnated with an antibiotic, which may reduce the incidence of bacteriuria. Nonrandomization can potentiate bias; however, in this study consecutive patients were enrolled, thus reducing bias. Antibiotics for non-UTIs may have altered the bacteriuria rates and organism types. Although there were insufficient data, it would be helpful to understand if an antireflux collecting system prevented specific organisms from causing bacteriuria.

\section{Methods}

A prospective, nonrandomized, controlled trial. The TCOS was used for the first 6 months and the CCDS for the next 6 months; the results for the two groups of patients were compared. All nurses were trained in urinary catheter care.

\section{Additional information}

\section{References}

1. Leone M, Garnier F, Dubuc M, Bimar MC, Martin C: Prevention of nosocomial urinary tract infection in ICU patients: comparison of effectiveness of two urinary drainage systems. Chest. 2001, 120: $220-224$.

This PDF file was created after publication. 